

\section{DISCLAIMER}

This report was prepared as an account of work sponsored by an agency of the United States Government. Neither the United States Government nor any agency Thereof, nor any of their employees, makes any warranty, express or implied, or assumes any legal liability or responsibility for the accuracy, completeness, or usefulness of any information, apparatus, product, or process disclosed, or represents that its use would not infringe privately owned rights. Reference herein to any specific commercial product, process, or service by trade name, trademark, manufacturer, or otherwise does not necessarily constitute or imply its endorsement, recommendation, or favoring by the United States Government or any agency thereof. The views and opinions of authors expressed herein do not necessarily state or reflect those of the United States Government or any agency thereof. 


\section{DISCLAIMER}

Portions of this document may be illegible in electronic image products. Images are produced from the best available original document. 


\section{DISCLAIMER}

This book was prepared as an account of work sponsored by an agency of the United States Government. Neither the United States Government nor any agency thereof, nor any of their employees, makes any warranty, express or implied, or assumes any legal liability or responsibility for the accuracy, completeness, or usefulness of any information, apparatus, product or process disclosed, or represents that its use would not infringe privately owned rights. References herein to any specific commercial product, process, or service by trade name, trademark, manufacturer, or otherwise, does not necessarily constitute or imply its endorsement, recommendation, or favoring by the United States Government or any agency thereof. The views and opinions of authors expressed herein do not necessarily state or reflect those of the United States Government or any agency thereof. 
EGG-FT- -5651

DE82 008609

\title{
DEVELOPMENT OF A NUCLEAR TEST STRATEGY \\ FOR TEST PROGRAM ELEMENT II
}

\author{
Gary A. De is \\ Peter $Y$. Hsu \\ John L. Liebenthal \\ Glen R. Longhurst \\ Lowell G. Miller \\ Richard E. Schmunk \\ Evert D. Uldrich \\ Robert $\dot{P}$. Wadk ins \\ Kenneth $D$. Watts
}

Published March 1982

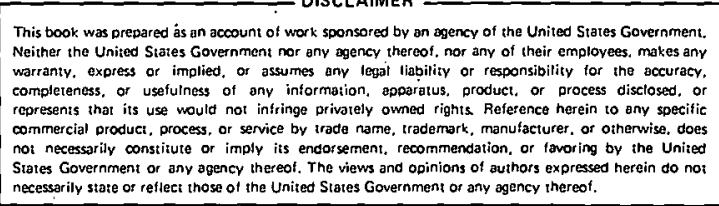

EG\&G Idaho, Inc.

Idaho Falls, Idaho 83415

Prepared for the

U.S. Department of Energy

Idaho Operations Office

Under DOE Contract No. DE-AC07-76ID01570

\section{NOTICE}

\section{PORTIONS OF THIS REPORT ARE ILLEGIBLE. It}

has been reproduced from the best available copy to permit the broadest possible availability. 


\title{
DEVELOPMENT OF A NUCLEAR TEST STRATEGY FOR \\ TEST PROGRAM ELEMENT II
}

\author{
Gary A. Deis \\ Peter Y. Hsu \\ John L. I. iehenthal \\ Glenr R. Longhurst \\ Lowell G. Miller \\ Richard E. Schmunk \\ Evert D. Uldrich \\ Robert $P$. Wadkins \\ Kenneth D. Watts
}

EG\&G Idaho, Inc.

Idaho Falls, Idaho 8341 ț

172

P.Y.S. Hsu, Manager

TPE-II Project

EG\&G Idaho, Inc.

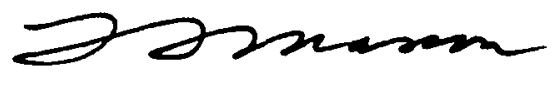

L. S. Masson, Manager

Fusion Technology Program

EG\&G Idaho, Inc. 


\section{ABSTRACT}

As part of Phase 0 in Test Program Element II of the Office of Fusion Energy's First Wall/Blanket/Shield Engineering Test Program, a test strategy has been developed to address the blanket/shield's (B/S's) thermal-hydraulic and thermomechanical data needs, which were identified in an earlier task through the use of nuclear and supporting nonnuclear testing. In Phase I, which extends through 1984, this strategy emphasizes the development of predesign information and the nonnuclear supporting tests. After Phase I, nuclear testing will be emphasized, and B/S design-verification testing will become more important. The proposed program will investigate a solid-breederblanket concept via nuclear testing. This program can begin in Phase I with nonnuclear support tests, and can progress to integrated nuclear testing soon after the completion of Phase I. The program's approximate cost and schedule are presented. In addition, other possible areas of study for Phase I, and strategies for the use of nuclear and nonnuclear facilities after Phase I are outlined. 


\section{CONTENTS}

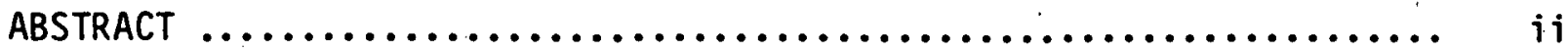

1. INTRODUCTION $\ldots \ldots \ldots \ldots \ldots \ldots \ldots \ldots \ldots \ldots \ldots \ldots \ldots \ldots \ldots \ldots \ldots \ldots \ldots \ldots \ldots$

2. TESTING ISSUES $\ldots \ldots \ldots \ldots \ldots \ldots \ldots \ldots \ldots \ldots \ldots \ldots \ldots \ldots \ldots \ldots \ldots \ldots \ldots$

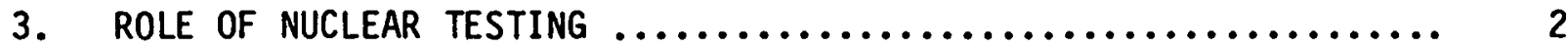

4. REVIEW OF DATA NEEDS $\ldots \ldots \ldots \ldots \ldots \ldots \ldots \ldots \ldots \ldots \ldots \ldots \ldots \ldots \ldots \ldots \ldots$

5. PROPOSED PHASE I NUCLEAR STRATEGY $\ldots \ldots \ldots \ldots \ldots \ldots \ldots \ldots \ldots \ldots \ldots \ldots$

5.1 Solid Breeder Concept Investigation ................ 4

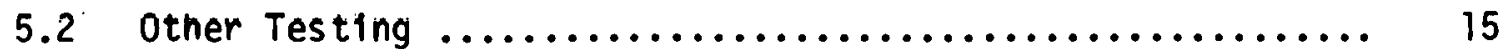

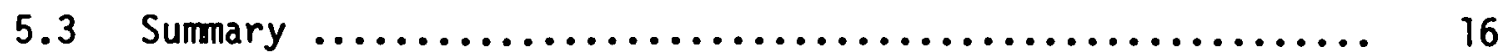

6. POST-PHASE-I TESTING $\ldots \ldots \ldots \ldots \ldots \ldots \ldots \ldots \ldots \ldots \ldots \ldots \ldots \ldots \ldots \ldots$

6.1 Strategy for Use of Nuclear Facilities ............... 19

6.2 Strategy for Use of Supporting Nonnuclear Facilities ..... 27

7. RECOMMENDATIONS $\ldots \ldots \ldots \ldots \ldots \ldots \ldots \ldots \ldots \ldots \ldots \ldots \ldots \ldots \ldots \ldots \ldots \ldots \ldots$

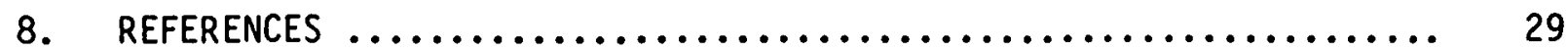




\section{INTRODUCTION}

As part of Phase 0 in Test Program Element II (TPE II) of the Office of Fusion Energy's First Wall/Blanket/Shield (FW/B/S) Engineering Test Program, the scope of work ${ }^{1}$ requires that a nuclear test strategy be developed which addresses both near-term (through 1984) and long-term testing. This strategy should employ both nuclear and supporting nonnuclear testing, and should investigate the critical data needs developed in Task 1.2. 2 The details of the nuclear test strategy developed by EG\&G Idaho are discussed in the following sections.

\section{TESTING ISSUES}

Considering the need for engineering testing of blanket shield ( $B / S$ ) components through 1990, it is apparent that only a preliminary list of . issues couid be considered for experimental investigation. One reason is that the available design information from many extant concepts is merely preliminary. Furthermore, new concepts will constantly evolve as the fusion program progresses, and the testing program must accommodate detajled data needs for these new concepts.

However, by examining the types of issues which have been identified, it is possible to develop two general categories of data needs which will also encompass all those yet to be identified. The first category (predesign testing issues) includes all of those data needs required to actually design $B / S$ components. This category includes both data needs concerning interactive behavior of engineering materials and basic thermal-hydraulic and thermomechanical design information. Information on issues in this classification must be available before a design can be developed. The second category includes all of those data needs which depend upon postdesign testing. These issues generally involve verification of predictions concerning the operation of a designed component or assembly. The distinguishing feature of this type of testing is that it cannot be performed until a design actually exists, and then the consideration is entirely design-specific. 
A11 of the data needs identified in Task 1.2 and discussed in section 4 of this report fall into the first category, with the exception of some tests concerning the low technology shield. This situation will probably not change significantly during Phase' I of TPE II, and thus it is expected that nearly all of the Phase-I testing will address predesign issues. When $B / S$ designs are developed, postdesign testing issues will become more important, and this type of testing could take place in the post-Phase-I time frame.

\section{ROLE OF NUCLEAR TESTING}

In order to develop an effective nuclear test strategy for the two classes of issues, it is important to understand the proper role of nuclear tests. Because nuclear tests will be costly, they should be employed only when necessary. Task $1.3^{3}$ revealed that nuclear testing is very effective in addressing thermomechanical and combined thermal-hydraulic/thermomechanical issues, but is less effective than other approaches in purely thermal-hydraulic experiments. Therefore, thermal-hydraulic issues generally should not be addressed by' nuclear testing. In cases where nuclear testing is useful, simulation approaches other than nuclear heating should be used extensively before nuclear testing is undertaken.

The application of nuclear testing is somewhat different for the two basic types of testing issues. In predesign testing, nuclear simulations should be employed mainly when the issue depends on the effects of radiation other than bulk heating. In predesign tests, which are generally small, it , is often possible to adequately simulate bulk heating by nonnuclear approaches. However, some engineering effects depend so strongly on combinations of stress, temperature, and radiation that nuclear testing is almost. mandatory. For many of these issues, the neutron spectrum (particularly the $14 \mathrm{MeV}$ component) is quite important. Typically, however, these are material issues and are therefore not within the scope of TPE II. In other cases, such as the study of the thermal-hydraulic and thermomechanical effects of tritium breeding, the particular spectrum employed for testing is not as important, because (for instance) lithium enrichment can be tailored to compensate for spectrum changes. 
The main application of nuclear simulation is in postdesign testing. Naturally, nonnuclear simulations must again be extensively employed to learn as much as possible before nuclear testing. However, because integrated system performance often depends on fine details of the simulation, the most realistic available simulation must be used at some time. In addition, as the test pieces considered increase in complexity (as they must in postdesign testing) it becomes increasingly difficult to develop an acceptable nonnuclear simulation. Thus, the role of nuclear testing in addressing postdesign issues is primarily. in the final verification test of integrated system performance.

In order to be useful in addressing B/S thermal-hydraulics and thermomechanics, a nuclear facility must have a large test volume and high power. For this reason, facilities such as FMIT, RTNS, and other accelerator-based facilities are not expected to be particularly useful in thermal-hydraulic or thermomechanical testing. Near-term fusion devices, such as TFTR, have adequate test volumes, but are limited in power, pulse length, or duty cycle, and will therefore probably not be useful. However, some fission reactors do provide the necessary combination of power and test volume. These are discussed in another report ${ }^{4}$. For the purpose of developing the nuclear test strategy, it is assumed that all nuclear testing before the operation of a fusion engineering device will be performed in available fission facilities.

The preceding general concepts are employed in the following sections to develop the nuclear test strategy for TPE II. In section 4, data needs already identified are discussed as a prelude to the delineation (in section 5) of preconceptual designs of nuclear and supporting nonnuclear experiments to address such needs. These experiments primarily address predesign testing issues. In section 6, a general approach is presented for the use of nuclear testing, and nuclear and nonnuclear facilities, after Phase I. Finally, in section 7, specific recommendations are made for application of this nuclear test strategy. 


\section{REVIEW OF DATA NEEDS}

The data needs identified in Task 1.2 include both predesign data and postdesign verification data needs. Task 1.2 revealed that the data needs for near-term, low-technology shields such as are planned for the fusion engineering device (FED) are of a confirmatory type. Since these shield designs are not well-developed at this time, it is not possible to identify specific verification issues or the exact testing which will be required. However, as shield designs evolve, verification testing should be undertaken.

Higher technology blankets which involve tritium production and high temperatures have many data needs of both types. A number of data needs concerning solid breeder blanket concepts (discussed in detail in Reference 2) are of immediate importance. The data needed are in the areas of: (a) contact resistance; (b) heat-transfer behavior; (c) effective thermal conductivity; (d) purge flow distribution; (e) thermal ratcheting. These predesign data needs must be resolved before credible solid breeder blankets can be designed; consequently, this area was felt to be an appropriate starting point for experimental investigation in Phase I.

\section{PROPOSED PHASE I NUCLEAR STRATEGY}

Investigation of the solid breeder blanket concept has been identified as the most important area for immediate pursuit, and will be the bas is of the Phase-I nuclear strategy. The components of this investigation are discussed in the following section. In section 5.2, other possible areas for investigation during Phase I are discussed.

\subsection{Solid Breeder Concept Investigation}

The requirements for an effective nuclear test program include substantial nonnuclear testing. The nonnuclear tests must generate the information required to properly perform the subsequent nuclear tests. For this reason, the description of the nuclear strategy for the solid breeder 
investigation will begin with the nuclear test, and will then develop the nonnuclear tests needed for support information. At each stage, discussion of the data obtained from each experiment will be included.

\subsubsection{Solid Breeder Concept Nuclear Test}

The nuclear testing in which the solid breeder investigation culminates will address two types of issues. First, such testing will attempt to validate the results of the preceding nonnuclear tests. Since nonnuclear tests can only partially simulate bulk heating, the results of nonnuclear tests must be compared with nuclear tests, which involve more realistic bulk heating. The second type of issue involves radiation effects on the thermalhydraulics and thermomechanics. It is likely that the tritium breeding reaction will cause microscopic changes in materials, which will in turn cause changes in such parameters as temperature or flow distributions. These issues cannot be acceptably investigated by nonnuclear experiments.

The nuclear experiment in the solid breeder investigation should irradiate a un it cell in a solid breeder concept, including cooling and purge flows at appropriate conditions. A typical unit cell for the STARFIRE concept, for instance, would consist of a prismatic block of solid breeder with a central coolant tube (Figure 1). In addition, an internal purge flow should be included. The test piece should have a supporting coolant system with appropriate pumps, pressurizers, and heat exchangers, as well as a purge system with helium circulators, heat exchangers and tritium processors. Some provision should be made for applying cyclic heating by employing either a movable flux absorber or a device to move the test piece out of the neutron flux. Finally, pretest and posttest examination of the test piece should be employed to detect changes which might heip to interpret the experimental data.

Many issues could be examined in this type of test. Most will be thermal-hydraulic and thermomechanical manifestations of temperature- and radiation-induced changes. It is projected that the properties of solid breeder materials depend on both radiation and operating temperature in a synergistir. manner. The nuclear test environment should produce both the 


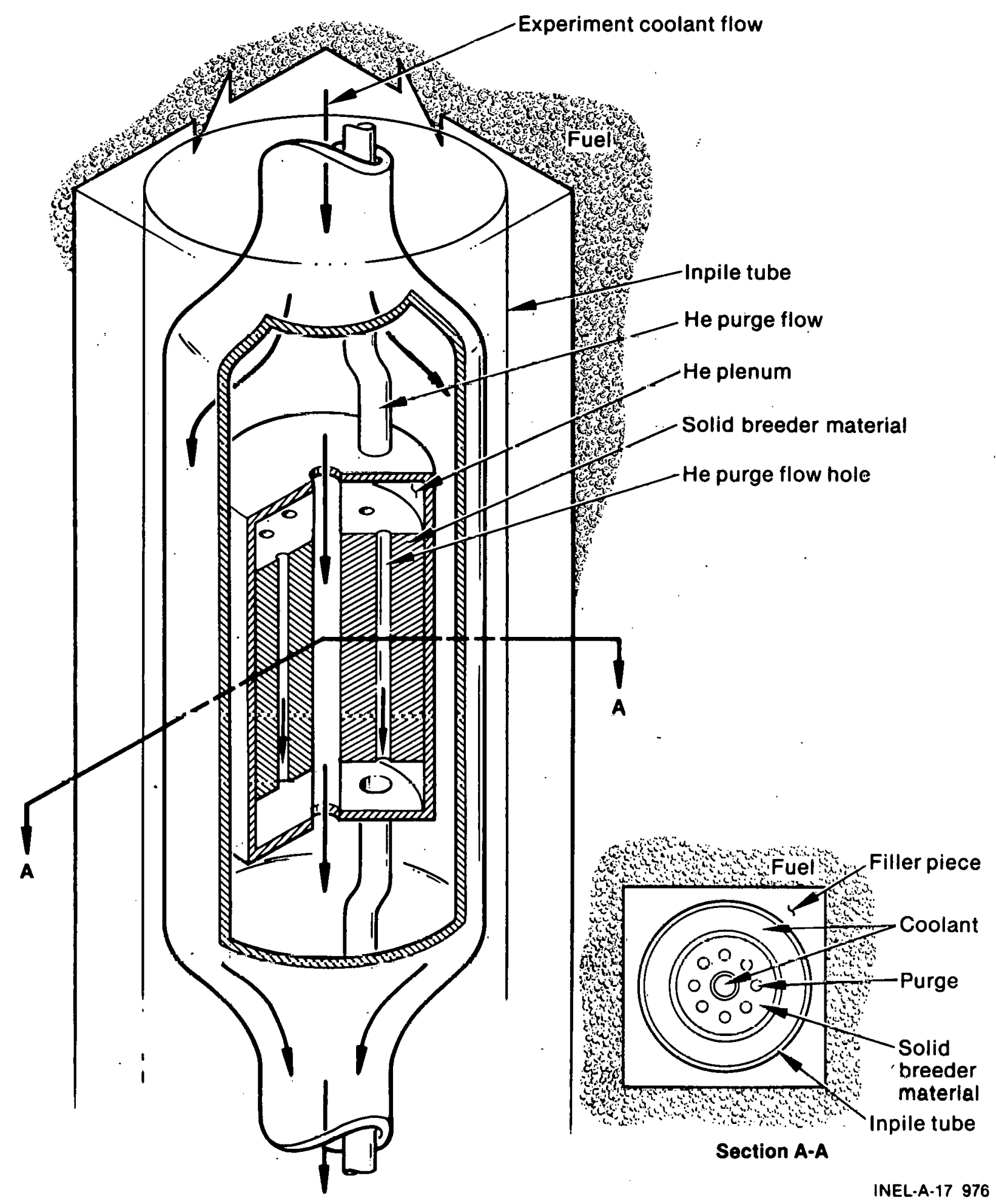

Figure 1. I sometric cutaway view of a possible solid breeder nuclear test. 
correct temperature profile and the radiation required to develop the complex time and space variations in the material properties. For instance, since tritium will actually be produced as a result of the neutron flux, the effects of the breeding reaction and its by-products on the solid breeder properties can be observed. It is expected that burnup of lithium with time will not significantly affect the temperature profile in the test piece, but this issue is currently being examined.

These microscopic effects will have observable macroscopic effects. Significant change of the thermophysical properties of the breeder will alter the internal temperature profiles. Dimensional changes and ratcheting problems can be affected. In addition, redirection of the purge flow and increased tritium retention can occur. These macroscopic effects can, with proper instrumentation, be detected and correlated with the microscopic material changes, as determined from pre- and posttest examinations.

In addition to these radiation-related concerns, effects relating to bulk heating $c$ an be examined. The primary concern is how the true bulk heating profile affects the results of the previous, non-bulk-heated experiments. It is likely, for instance, that the shape of the temperature distribution in the solid breeder will have a great effect on thermal distortion, gross fracturing, and thermal ratcheting. These effects may in turn have impact on the heat transfer and thermal-hydraulics in such areas as purge flow distribution, and contact or gap resistance.

Given a proper detailed-design of the nuclear tests, all these effects $c$ an be studied. As was mentioned previously, the emphas is in this test series should be on integrated systems testing. Nonnuclear experimental information should be available for each effect before the test is undertaken. The tests which contribute this information are discussed in the following section.

\subsubsection{Supporting Nonnuclear Tests}

Nonnuclear testing should begin with simple experiments designed to yield information for use in later, more complex experiments, event.ually 
leading to nuclear testing. The first experiments should examine individual effects. One such scoping experiment could study basic characteristics of purge flow through an isothermal solid breeder material, as a function of temperature and time. Since the properties of the breeder material are expected to change with time, this experiment could provide some of the information required to detect these changes via their macroscopic effects. This test could use a small capsule of solid breeder material (with a purge inlet and outlet), which could be heated in a tube-type furnace (Figure 2). With flow-rate versus pressure-drop information, along with pre- and posttest examination of the test piece, the basic dependences of the flow characteristics on temperature and time could be determined. In later stages, this experiment might be expanded to include cyclic heating, in order to investigate its effects (if any) on purge flow, and to gather some basic data on the mechanical stability of the breeder. This information could then be applied in the design and analys is of the nonnuclear simulation tests and the nuclear test.

The next test series should include the added complication of a temperature gradient through the breeder material. These experiments would be similar to the earlier series, except that a coolant tube would be added to the capsule. The test piece configuration used for this test series (Figure 3) should closely resemble that for the nuclear test, so that test results can be directily applied. The thermal gradient should be obtained by heating the outside of the capsule and cooling the center, in order to simulate the temperature profile of actual conditions. The initial tests of this series should be steady-state tests, which will yield information on purge flow and material changes as functions of temperature and time. In addition, gross mechanical behavior of the breeder/tube system, and effective heat transfer through the breeder and from breeder to tube could be investigated. Since a range of temperatures will be present in the breeder, posttest examination can be quite useful in correlating material changes with temperature-time histories. The later experiments in this series of tests should include cyclic heating. The primary concerns in these tests will be the mechanical-stability of the breeder and the characteristics of the breeder/tube interface. These issues include thermal 

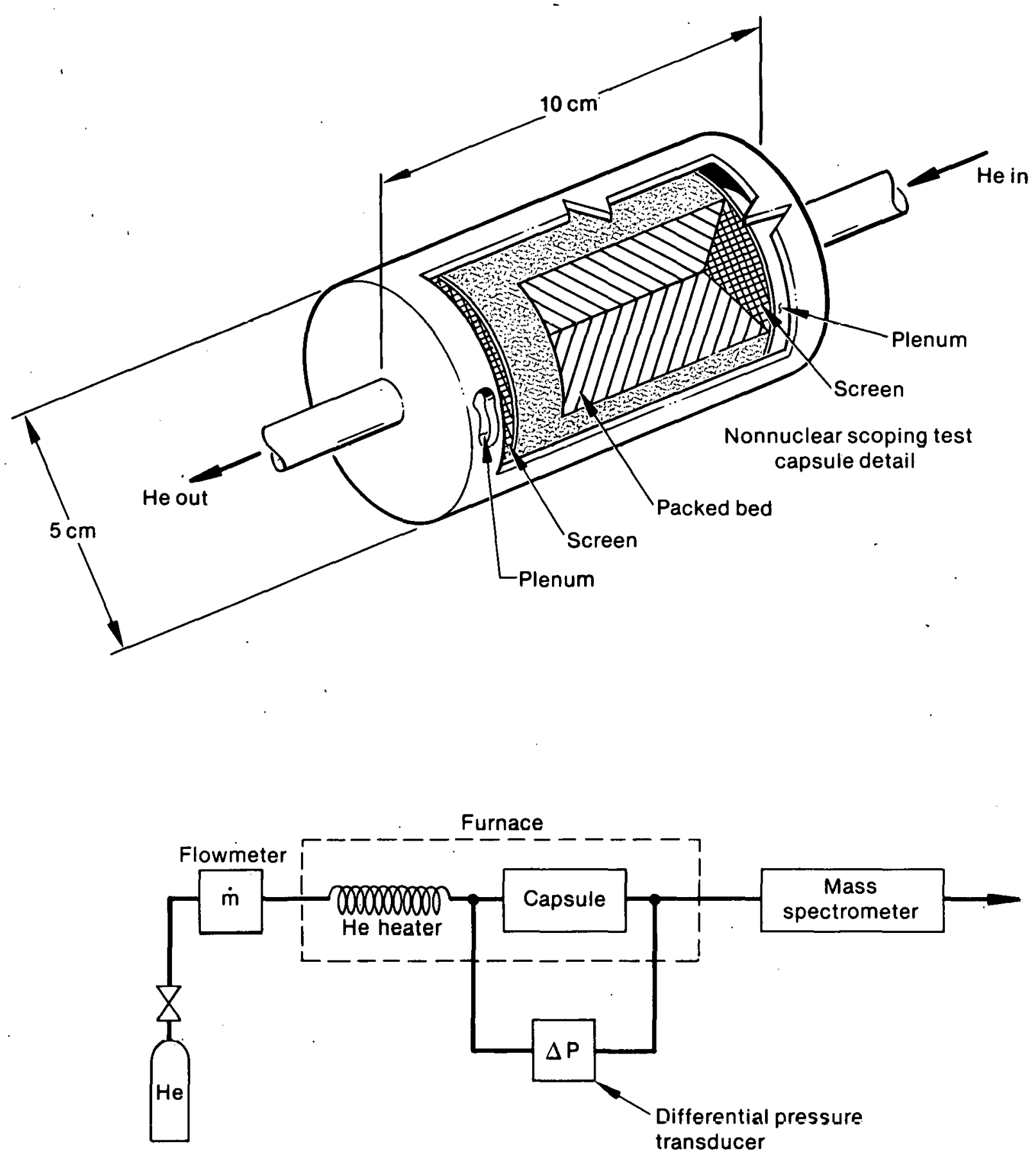

INEL-A-17 977

Figure 2. Schematic of initial nonnuclear solid breeder experiment. 


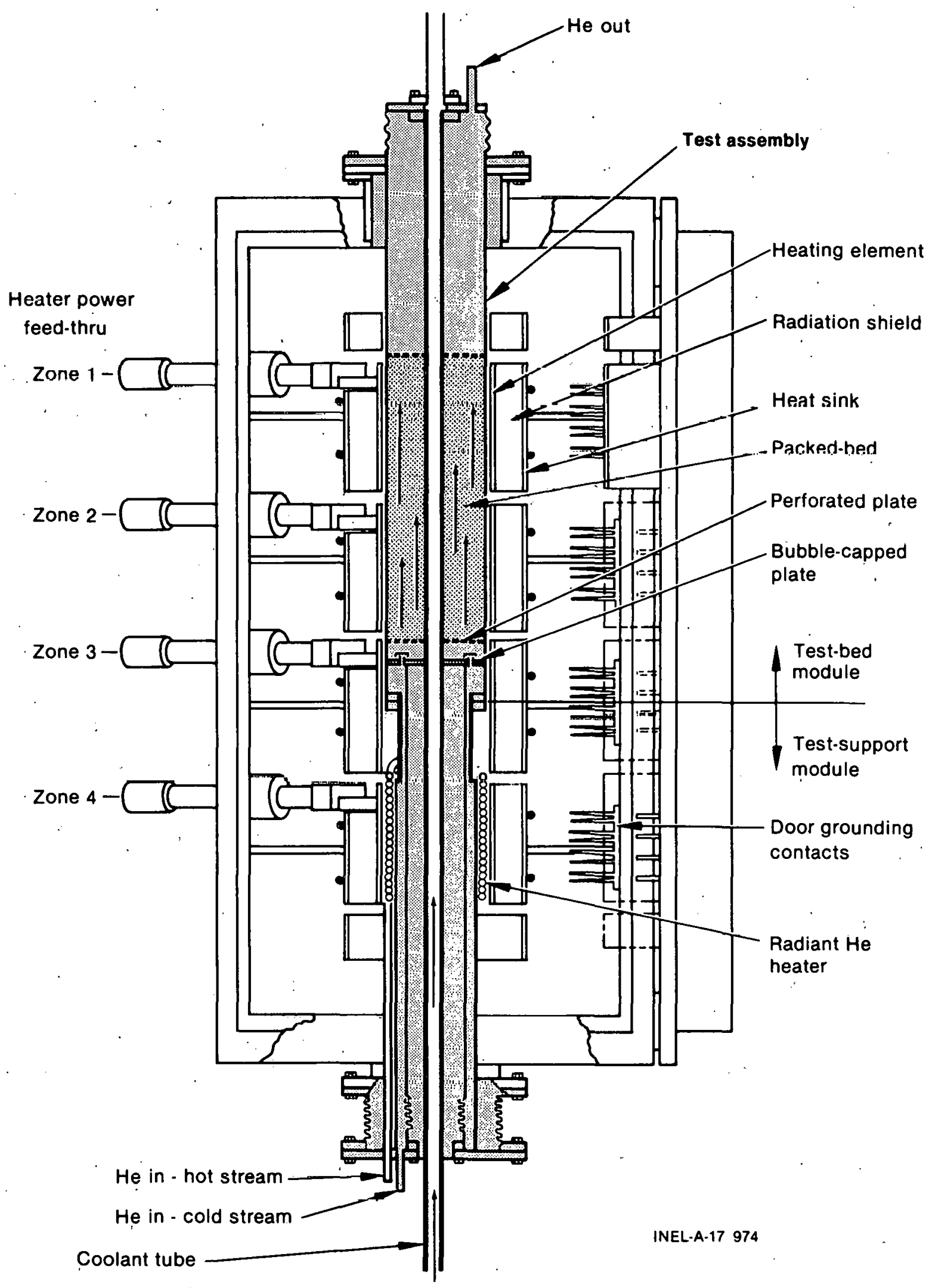

Figure 3. Schematic of nonnuclear solid breeder test involving a temper ature gradient. 
ratcheting effects, and the heat transfer problems resulting from differential expansion of the breeder and coolant tube. In addition, effects on purge flow could be studied. Information from similar earlier tests, which did not include thermal gradients, should be used to develop performance predictions. Similarly, information from these tests should be used to predict the performance of later'nuclear tests.

There will be great similarity between the nonnuclear tests designed to support nuclear experiments and those conducted for purely nonnuclear purposes. Therefore, additional information on supporting nonnuclear testing $c$ an be found in the nonnuclear strategy report prepared under Task $1.4^{5}$.

\subsubsection{Cost and Schedule Information}

Table 1 summarizes the experiments which comprise the nuclear strategy for a solid breeder concept investigation. Figure 4 shows a preliminary schedule for this program. All tests to be conducted in Phase I are nonnuclear, but it is assumed that nuclear testing will commence soon thereafter. For this reason, planning and design activities in support of the postPhase-I nuclear tests must take place during Phase 1 . Given the schedule shown in Figure 4, purchase of long-lead items for the nuclear tests would be made in Apri1, 1984, and the first nuclear tests would begin in April, 1985.

The approximate cost for the Phase I program is detailed in Table 2. The expected funding required after Phase I for nuclear testing of solid breeder blanket concepts is indicated in Table 3 for three different test options. The first option involves steady-state testing using low-pressure (150 psi) water as coolant. Option 2 also involves steady-state testing, but includes pressurized (2000 psi) water coolant. Option 3 extends the testing to include cyclic heating. In all cases, it is assumed that maximum use is made of existing components (in-pile tubes, etc.). The facility cost shown is the approximate cost of making required modifications to the 


\begin{tabular}{|c|c|c|}
\hline $\begin{array}{c}\text { Exper iment } \\
\text { Ser ies } \\
\end{array}$ & Test Configuration & $\begin{array}{c}\text { Types of Effects } \\
\text { Addressed }\end{array}$ \\
\hline 1 & $\begin{array}{l}\text { Steady-state scoping test. } \\
\text { Small, isothermal breeder } \\
\text { capsule, with purge flow and } \\
\text { steady-state heating. (2 tests) }\end{array}$ & $\begin{array}{l}\text { Purge flow character istics. } \\
\text { Material changes as a } \\
\text { function of temperature } \\
\text { and time. }\end{array}$ \\
\hline 2 & $\begin{array}{l}\text { Cyclic scoping test. } \\
\text { Small, isothermal breeder } \\
\text { capsule, with purge flow and } \\
\text { cyclic heating. (1 test) }\end{array}$ & $\begin{array}{l}\text { Purge flow characteristics. } \\
\text { Breeder mechanical } \\
\text { stability. }\end{array}$ \\
\hline 3 & $\begin{array}{l}\text { Steady-state simulation test. } \\
\text { Capsule with external steady- } \\
\text { state neating, internal cooling, } \\
\text { and purge flow. ( } 2 \text { tests) }\end{array}$ & $\begin{array}{l}\text { Purge flow characteristics } \\
\text { in non isothermal breeder. } \\
\text { Material changes as a } \\
\text { function of temperature } \\
\text { and time. } \\
\text { Breeder mechanical } \\
\text { stability. } \\
\text { Effective heat transfer. } \\
\text { Breeder/tube mechanical } \\
\text { interaction. }\end{array}$ \\
\hline 4 & $\begin{array}{l}\text { Cyclic simulation test. } \\
\text { Capsule with external rys.lir. } \\
\text { heating, internal cooling, } \\
\text { and purge flow. (l test) }\end{array}$ & $\begin{array}{l}\text { Purge flow characteristics. } \\
\text { Mater ial rhanges: } \\
\text { Breeder mechanical } \\
\text { stability. } \\
\text { Effective heat transfer. } \\
\text { Breeder/tube mechanical } \\
\text { interaction. }\end{array}$ \\
\hline 5 & $\begin{array}{l}\text { Steady-state nuclear test. } \\
\text { Capsule with steady-state } \\
\text { nuclear heating, internal } \\
\text { cooling, purge flow, and } \\
\text { tritium removal. }\end{array}$ & $\begin{array}{l}\text { Radiation effects on: } \\
\text { Purge flow } \\
\text { Material changes } \\
\text { Breeder mechan ical } \\
\text { Stability } \\
\text { Effective heat transfer } \\
\text { Breeder/tube interaction } \\
\text { Tritium production. }\end{array}$ \\
\hline 6 & $\begin{array}{l}\text { Cyclic nuclear test. } \\
\text { Capsule with time-variable } \\
\text { nuclear heating, internal } \\
\text { cool ing, purge flow, and } \\
\text { tritium removal. }\end{array}$ & $\begin{array}{l}\text { Radiation effects on: } \\
\text { Purge flow } \\
\text { Material changes } \\
\text { Breeder mechanical } \\
\text { Stability } \\
\text { Effective heat transfer } \\
\text { Breeder/tube interaction } \\
\text { Tritium production. }\end{array}$ \\
\hline
\end{tabular}




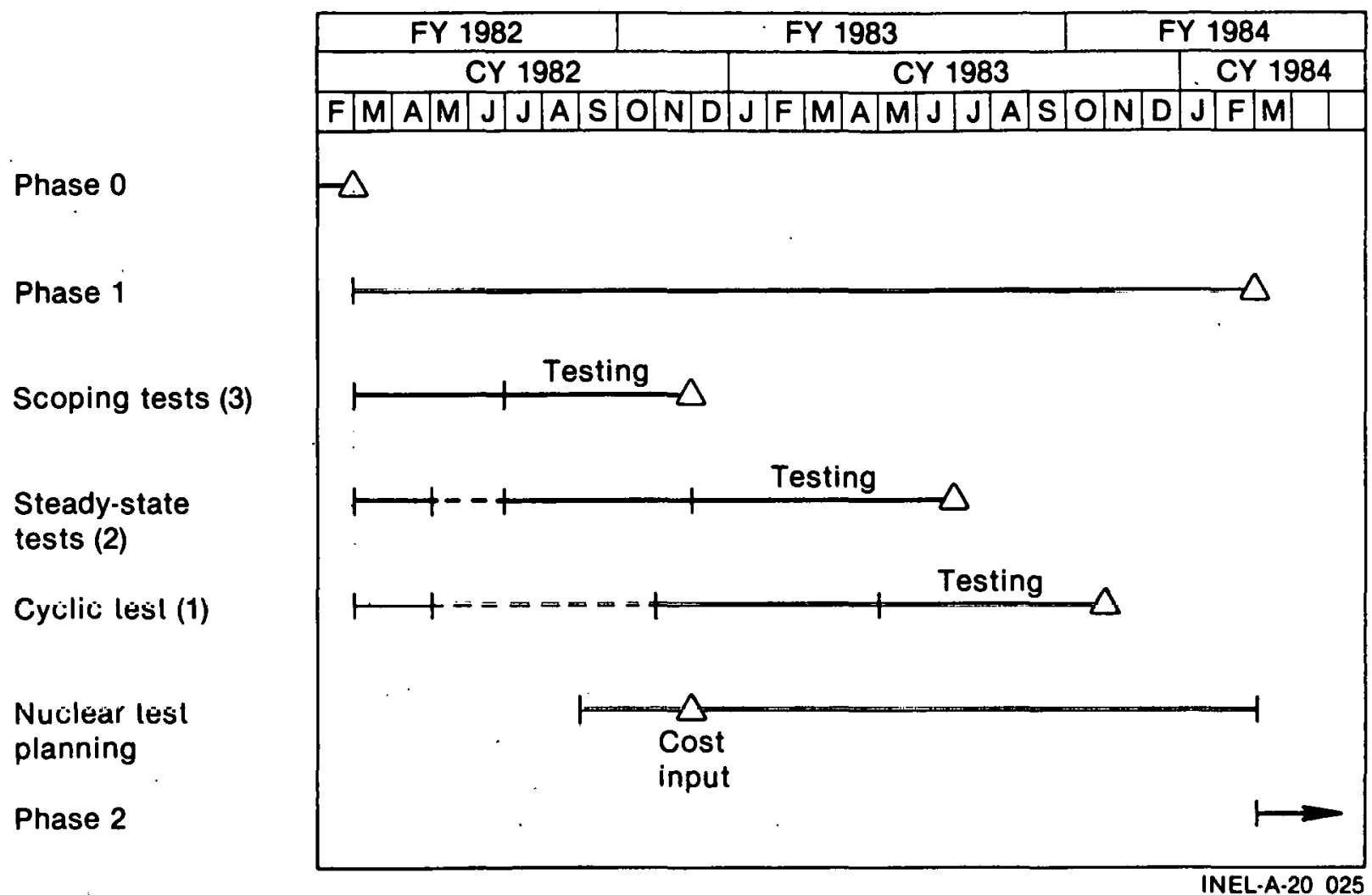

Figure 4. Preliminary program schedule for a solid breeder concept investigation.

TABLE 2. APPROXIMATE COST OF PHASE. I PROGRAM

Cost (KS)

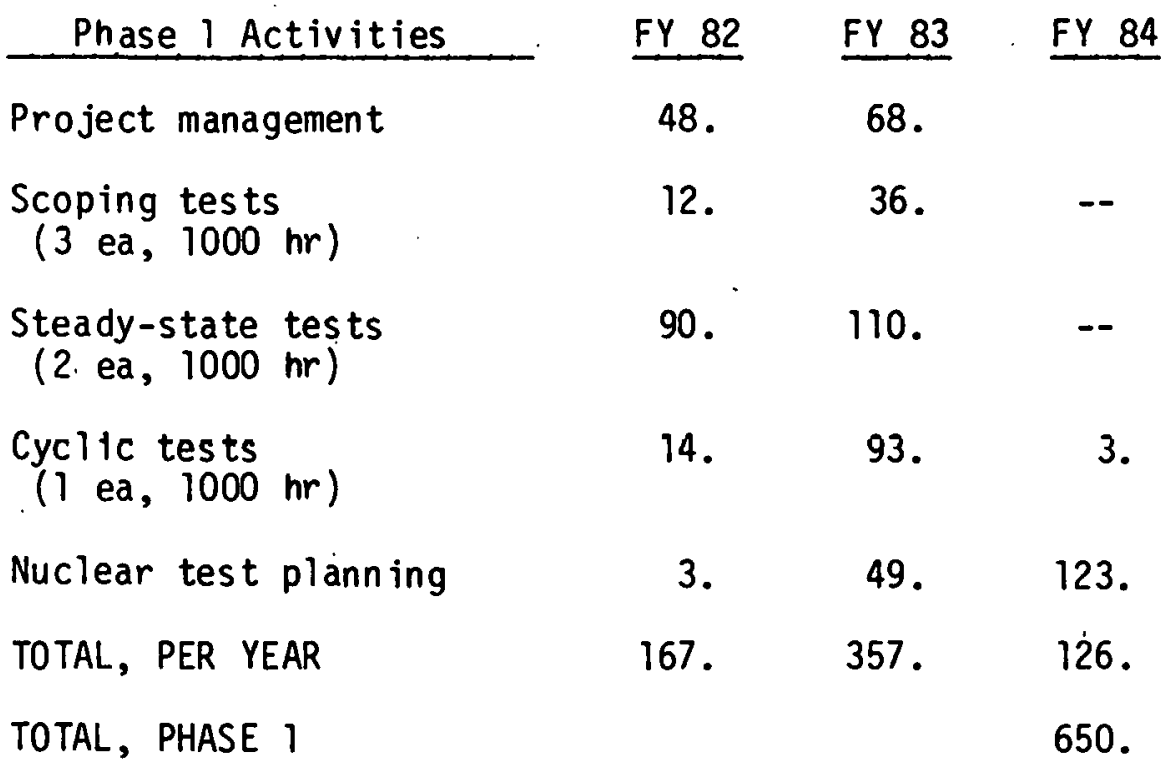


TABLE 3. APPROXIMATE COST OF POST-PHASE-I SOLID BREEDER CONCEPT NUCLEAR TESTS

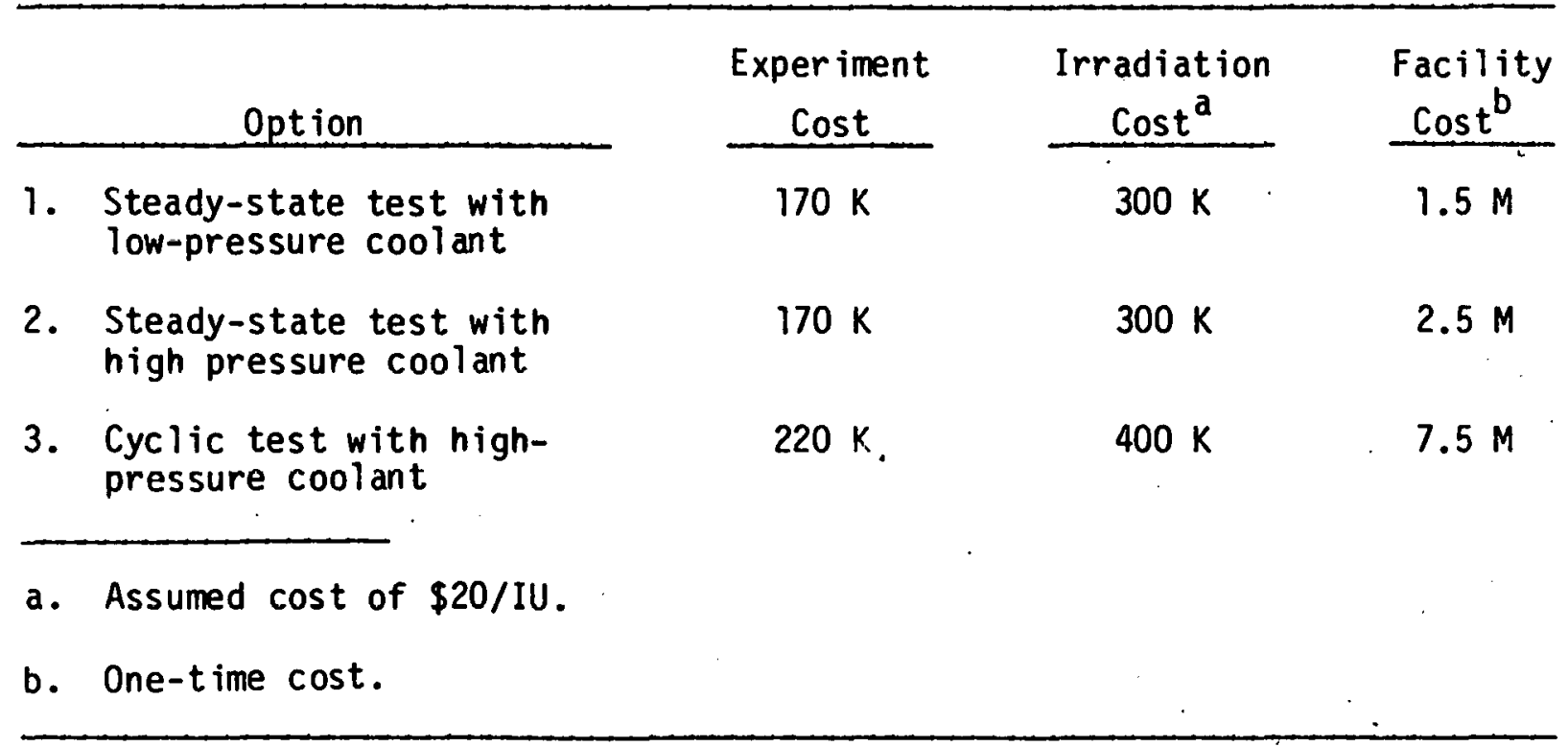

reactor (e.g., installation of the in-pile tube and cooling-loop hardware). Therefore, this cost must be paid only once, regardless of how many tests of, a given type are performed.

\section{1 .4 Summary}

The experiments which comprise the nuclear approach proposed for a solid breeder concept investigation are summarized in Table 1. Each experiment contributes information which is required in order to understand the results of the next, and the experiments lead directly to a series of integrated nuclear tests. Such a program could contribute much critical information to the solid-breeder design data base. If this program is completed, efforts could then be directed toward a power-producing, tritium-breeding, blanket design.

The experiments listed.in Table 2 do not include some of those identified in the nonnuclear strategy (Reference 5). While several of the experiments omitted in Table 2 are useful to a nuclear testing program, budgetary realities suggest that a more strongly focussed program should be pursued for a nuclear strategy. While nonnuclear testing can address issues for a 
variety of candidate systems, the greater costs associated with nuclear testing imply that the available resources should be concentrated on the most promising candidate(s).

As shown in Table 3, several nuclear test options may be pursued-depending on available resources. While the costs for any of these options are higher than for corresponding nonnuclear tests, it must be remembered that the mission success of a multibillion dollar facility could be severely compromised by neglecting this aspect of testing.

\subsection{Other Testing}

The review of data needs showed that the solid-breeder-blanket concept has the greatest need for investigation via nuclear testing. The testing proposed above on the solid breeder concept will serve two functions. Such testing will provide some basic information for the blanket designer, and will provide some initial operating experience with a module employing solid breeder technology. Though both functions lie in the predesign category of testing (as opposed to design verification), the latter function serves as a concept verification test--in that it should reveal any synergistic effects or other important unknowns which must be accommodated in the $B / S$ design.

It was inferred from the data needs assessment that thermal-hydraulic and thermomechanical data required for B/S design concepts (other than solid breeder) are less urgent. Hence, if testing of other concepts is considered for Phase I, such testing should address what was previously referred to as concept verification. That is, a representative test piece would be assembled using a generalized configuration and technologies representative of those used in a given B/S concept. For example, a stainless steel canister with flowing liquid lithium and representative joints and seals could be assembled. Nonnuclear tests would be conducted to ascertain the thermal and hydraulic characteristics of the test piece, which would then be operated in a test hole of a fission reactor. Sufficient fluence and thermal cycling would be achieved to determine the behavior of the test piece in the nuclear environment. ubservations would be compared with predictions 
to verify that all important effects had been accounted for. The choice of concept to evaluate in this way is relatively open. Variations on the solid breeder concept investigated in the principal test would perhaps be less expens ive than liquid metal experiments, but the latter may be more desirable.

With the exception of the liquid metal concepts, testing the various other B/S concepts would require approximately the same funding as those outlined for solid breeder testing. If a nuclear reactor is employed, the overall project cost would be similar for gas or water coolant, or for any structural configuration of the test piece. The reactor facility costs would dominate in nuclear testing. Where 1 iquid metals are employed, however, that generalization would not be accurate because of the extensive and specialized equipment needed to heat, clean, transport and recover liquid metal. Detailed costs of the various options available, and plans for conducting experiments using alternate concepts will not be developed here. The cost data provided for the solid breeder testing are considered typical. Alternate $p l$ ans and budgets can be developed with reasonable dispatch.

\subsection{Summary}

The preceding outline for a nuclear B/S test program could satisfy the data needs delineated here and elsewhere. Further details will be developed and reported in the future under TPE II Tasks 1.6 and 1.7 . It is anticipated that the nuclear $B / S$ test program could be undertaken immediately, in Phase I of TPE II, and could extend into later testing phases (after 1984).

After 1984, tests may be undertaken in other areas with in TPE II, based on new information or new module concepts. In addition, postdesign testing will become important. The approach to resolving these post-Phase-I issues is described in the following section. 


\section{POST-PHASE-I TESTING}

The tests following Phase I will depend strongly on the direction of the national and international fusion programs in the next several years. At the present time, this direction is not clearly apparent. However, two general approaches may be considered.

In the first general approach, an engineering test device such as the FED would be constructed as the next major step. This device would employ mainly present-day technology, and would not include a tritium-breeding blanket or electrical power production capability. However, because of moderate neutron wall loading, the device would serve as a test bed for component engineering development and verification studies. The next step would be to create a systems integration device, perhaps similar to INTOR, which would address the construction and operation of a fusion device with all of the necessary support systems--including those required for tritium breeding and electrical power production. The following step would create an optimized demonstration power plant. If this first general strategy is pursued, two types of $B / S$ testing will be necessary. First, in support of the design and construction of the FED, verification testing of the shield would be necessary prior to construction. It is likely that the shield would have a low temperature design, similar to the FED shield, and thus would require little or no predesign testing. Following this shield design-verification testing, blanket test module designs would require testing. This would involve both the development of design data relating to tritium breeding blankets, and design verification testing to qualify modules for testing on the engineering test device.

A second general approach might omit the engineering device. Thus, construction of the systems integration device would be the next major step, followed by the construction of an optimized demonstration power plant. If this second approach is used, two testing areas would again be important. In support of the systems integration device, verification testing of the biological shield would be necessary, as would both predesign data base development and postdesign verification of the built-in breeding blanket (the latter is assumed to be present for economic reasons). All of this 
testing would be necessary before completing construction of the machine, because components for the machine itself would be undergoing testing.

In comparing the requirements for $B / S$ testing from these two possible scenarios, it is apparent that the needs are similar. However, if the first approach is used, it is likely that the engineering device would be built sooner than the systems integration device would be built using the second approach. Thus, blanket testing would be needed at nearly the same time in either scenario. Blanket test modules for a demonstration power reactor would require testing on an INTOR-like device by approximately 1998. The proof testing of the integral breeding blanket which would probably be included on the INTOR-like reactor would then be conducted about 1990-1992. If this machine is the next one built, it would need proof testing of the shield at about the same time. If a lower technology machine precedes the systems integration device, then it may require shield verification data somewhat earlier, though the difference in time should be relatively small. For the purpose of outlining the types of testing to be conducted after Phase I, it is assumed that the timing of both blanket and shield requirements is unaffected by the choice of scenario. If the program proceeds in a significantly different direction than anticipated, post-Pnase-I activities can be reassessed.

Given these assumptions, the post-Phase-I period (1984-1990) will be characterized by two kinds of activity. The early years (1984-86) will be a period of $B / S$ conceptual designs. During these early years, the $B / S$ system will be undergoing design activities similar to those that the magnet systems are undergoing at present. Incidental to such design activity will be specific requirements for engineering data to support various aspects of the evolving designs. While every effort will be made in Phase I to anticipate such requirements, some additional information critical to an evolving design will probably be needed. We anticipate that most of the work during the 1984-1986 period will be in response to needs of this kind. Thus, such work will be in effect an extension of the Phase-I activity.

During the latter period following Phase I, testing will assume a different character. It is expected that the principal activity under TPE II 
for the late 1980's will be design verification testing on B/S test modules and systems. In this time period, preliminary and/or final design of the biological shield for the next machine will begin, and verification of this design will become important. Also, preliminary or final design activity will begin on breeding blanket modules. These modules will be used either. to generate an entire blanket system for incorporation into a system integration device, or as test modules to be used on an engineering test device. It is likely that more than one $B / S$ design will progress far enough to require some design verification testing.

\subsection{Strategy for Use of Nuclear Facilities}

Requirements for nuclear test facilities in the early years of postPhase-I activity will depend upon the progress made in Phase-I testing and upon the identification of additional needs during $B / S$ design. There is presently no firm requirement for nuclear facility testing to resolve critical engineering data needs beyond those identified in Phase I. The real need for nuclear test facilities in the post-Phase-I time frame will be in the design verification tests. The following needs are particularly important: verification of temperature profiles via true bulk heating; verification of resistance to thermal cyclic fatigue in a radiation environment; verification of flow stabilities over the range of possible operating conditions; and demonstration that synergistic effects between various aspects of the test environment will not pose any unforeseen difficulties.

One possible nuclear design-verification test would require that a $B / S$ module or subassembly (which would include an actual substructure with flow passages, joints, seals, etc.,) be placed in a fission reactor (see Figure 5). The test article would be equipped with necessary feedlines and duct work to operate for a sustained period in the reactor. Contingent on the fusion reactor design (periodic or steady-state), cyclic heating and radiation flux would be applied. Instrumentation would then monitor the dynamics of the test piece's operation. At the end of various fractions of design lifetime, the test piece would be removed from the reactor and examined under hot cell conditions to evaluate radiation damage and the overall 


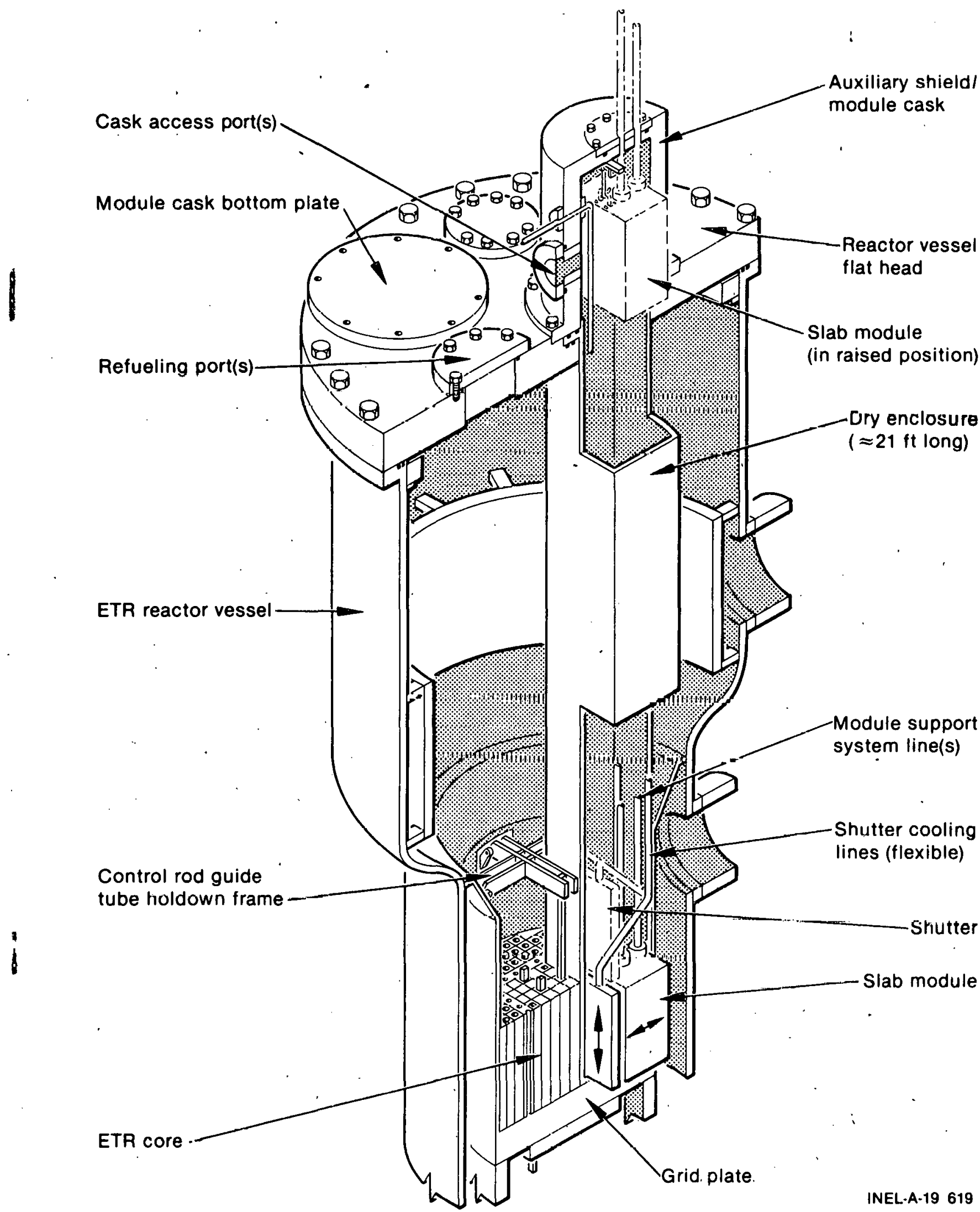

Figure 5. Example of a blanket module nuclear design verification test. 
condition of the test piece. Similar tests could be conducted on other subassemblies and even on complete modules (subject to volume limitations of the reactor test space).

Requirements for a nuclear reactor suited to a tes't of this type may be grouped in to three categories: volume, flux, and availability. The volume required depends on the size of the test piece. If meter-sized modules are to be tested, it will be necessary to use a reactor core which can be approached from one face in a large test space. No known research reactors have test holes allowing access to the core which can accommodate test pieces of this size. One option might be to restructure a core (see Figure 5). Another possibility might be to use a special purpose reactor in which a shield segment can be replaced by a fusion blanket test module. This capability could be incorporated in the design of a future fission reactor. For smaller, subassembly tests, several reactors presently in existence have test volumes large enough. Of course, a complex test item may require extensive connecting $l$ ines and fixtures--which would increase. the volumetric requirement. Volumetric capacities of candidate reactors are summarized in Table 4. Details of the test hole configuration are given in Table 5 .

The reactor flux requirements are principally those of providing representative bulk heating of the material. Estimates of nominal heating requirements $r$ ange from $2.7 \mathrm{~W} / \mathrm{cm}^{3}$ for a blanket on an INTOR device to $16-46 \mathrm{~W} / \mathrm{cm}^{3}$ for a power reactor blanket ${ }^{5}$. For heating purposes it is un important whether the energy is deposited by neutrons or gamma rays. Calculations performed for a typical blanket module positioned against a modified ETR core showed that with a neutron flux to the module surface of $3.4 \times 10^{14} \mathrm{n} / \mathrm{cm}^{2} \mathrm{~s}$, the bulk heating induced was equivalent to a neutron wall loading of $1.8 \mathrm{MW}^{2}$. Accordingly, fluxes less than this produce less representative heating rates. As an example, the 0 ak Ridge Research Reactor (ORR), which has a reported flux of $4 \times 10^{13} \mathrm{n} / \mathrm{cm}^{2} / \mathrm{s}$, will simulate a first wall loading of $0.2 \mathrm{MW} / \mathrm{m}^{2}$, making it less suitable for duplicating real time heating-- and therefore questionable for this type of testing. Fluxes for several fission reactors considered for fus ion blanket testing are also 1 isted in Tables 4 and 5 ; 
TABLE 4. REACTOR FLUX!'TEST VOLUNE MATRIX

Experiment volume (liters)

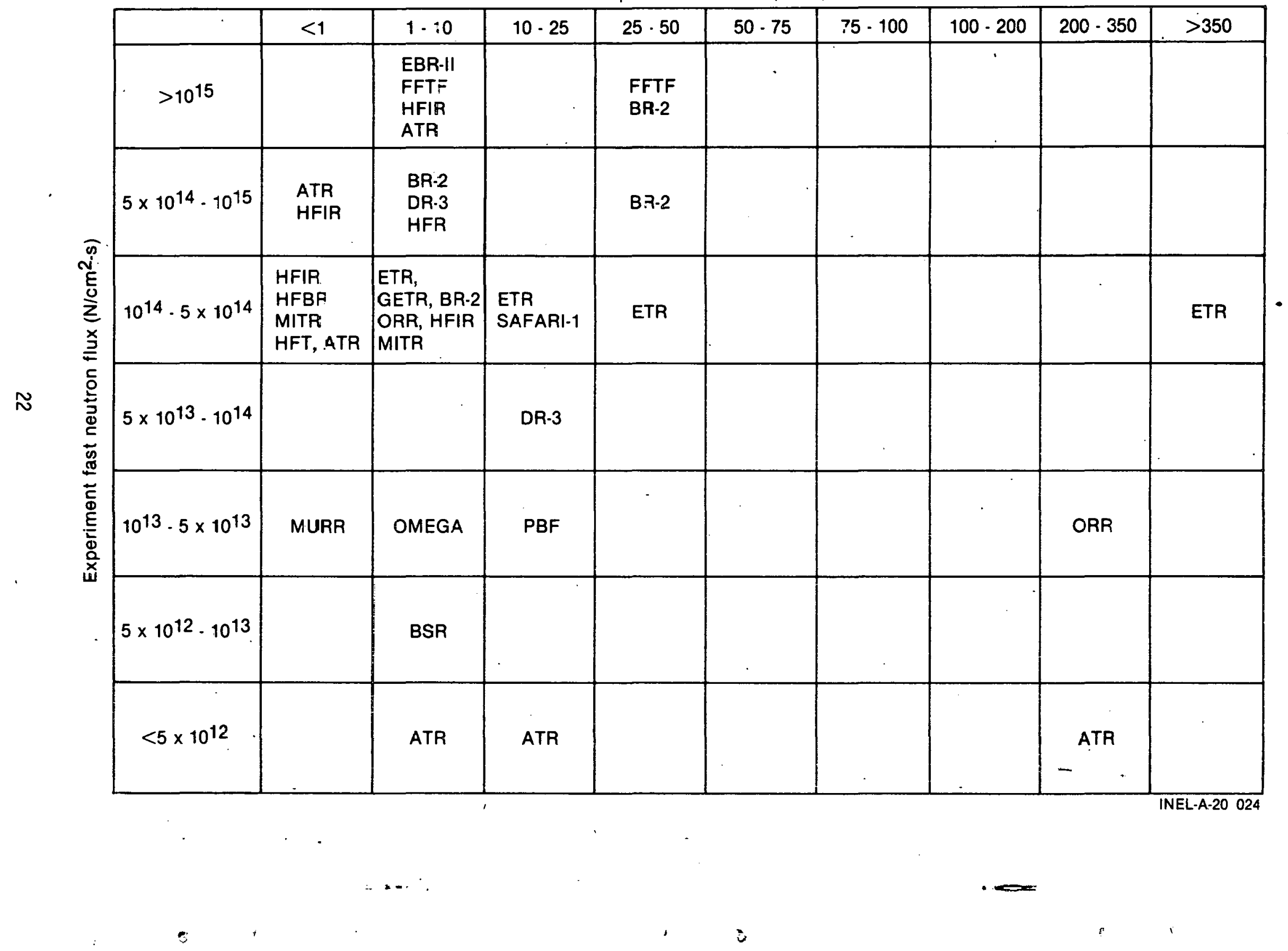


TABLE 5. REACTOR TEST VOLUME SIZES

\begin{tabular}{|c|c|c|c|c|c|c|}
\hline P.eactor & $\begin{array}{l}\text { Power } \\
\text { (MW) }\end{array}$ & & $\begin{array}{l}\text { xperiment } \\
\text { utron, } F \text { lux } \\
\left(n / \mathrm{cml}^{2} / \mathrm{s}\right)\end{array}$ & $\begin{array}{c}\text { Experiment Size } \\
(\mathrm{cm})^{\mathrm{a}}\end{array}$ & $\begin{array}{l}\text { Test Position } \\
\text { Experiment volume } \\
\text { (l) }\end{array}$ & Notes \\
\hline $\begin{array}{l}\text { EBR }- \text { I I } \\
\text { (I daho) }\end{array}$ & 62.5 & & $15 \mathrm{~F}$ & 7.4 dia $\times 36$ & 1.5 & Na cooling; in-core diameter \\
\hline $\begin{array}{l}\text { HFBR } \\
\text { (NER York) }\end{array}$ & 40 & $\begin{array}{l}5.5 \\
2.0\end{array}$ & $\begin{array}{ll}\times 10^{14} \text { thrm } \\
\times 10^{14} \text { fast }\end{array}$ & 2.4 dia $\times 7.6$ & 0.03 & $\begin{array}{l}\text { Central, peripheral and } \\
\text { reflector locations }\end{array}$ \\
\hline $\begin{array}{l}\text { ATR } \\
\text { (I daho) }\end{array}$ & 250 & $\begin{array}{r}5.3 \\
1.9 \\
3.8 \\
3 \\
3 \\
2.8 \\
1.5\end{array}$ & $\begin{array}{l}\times 10^{14} \text { fast } \\
\times 10^{14} \text { fast } \\
\times 10^{14} \text { fast } \\
\times 10^{12} \text { fast } \\
\times 10^{12} \text { fast } \\
\times 10^{11} \text { fast } \\
\times 10^{15} \text { fast }\end{array}$ & $\begin{array}{l}1.5 \text { dia } \times 122 \\
2.2 \text { dia } \times 122 \\
1.6 \text { dia } \times 122 \\
12.5 \text { dia } \times 122 \\
8.1 \text { dia } \times 122 \\
5.3 \times 56.6 \times 122 \\
7.6 \text { dia } \times 122(9) *\end{array}$ & $\begin{array}{r}0.2 \\
0.5 \\
0.2 \\
14.9 \\
6.2 \\
312.8 \\
5.6\end{array}$ & $\begin{array}{l}12 \text { A-holes } \\
8 \text { B-holes } \\
16 \text { H-holes } \\
4 \text { I-holes } \\
16 \text { I-holes } \\
\text { Al1 0-holes together } \\
\text { Flux traps } \\
\text { * Thru-hole capability }\end{array}$ \\
\hline \multirow[t]{2}{*}{$\begin{array}{l}\text { ETR } \\
\text { (Idaho) }\end{array}$} & \multirow[t]{2}{*}{175} & $\begin{array}{r}4 \\
4\end{array}$ & $\begin{array}{l}\times 10^{14} \text { fast } \\
\times 10^{14} \text { fast }\end{array}$ & $\begin{array}{r}7.6 \text { sq } \times 91^{\star \star} \\
15.4 \text { sq } \times 91^{\star \star}\end{array}$ & $\begin{array}{r}5.3 \\
21.7\end{array}$ & \multirow[t]{2}{*}{$\begin{array}{l}\text { \# Thru-hole capability } \\
\text { * Modification required for large } \\
\text { blanket }\end{array}$} \\
\hline & & $\begin{array}{r}4 \\
4 \\
3.4\end{array}$ & $\begin{array}{ll}\times 10^{14} \text { fast } \\
\times 10^{14} \text { fast } \\
\times 10^{14} \text { fast }\end{array}$ & $\begin{array}{l}15.4 \times 22.9 \times 91 \star \star \\
22.459 \times 91 * \star \\
65 \times 76 \times 91 *\end{array}$ & $\begin{array}{r}32.2 \\
47.9 \\
451.3\end{array}$ & \\
\hline $\begin{array}{l}\text { LOF } \\
\text { (I daho) }\end{array}$ & 50 & & $N / A$ & No test positions & -- & . \\
\hline $\begin{array}{l}\text { PBF } \\
\text { (Idaho) }\end{array}$ & 28 & 2 & $\times 10^{13}$ fast & 15.5 dia $\times 91$ & 17.2 & $\begin{array}{l}\text { At } 28 \mathrm{MH} / \mathrm{max} \text { power } 270 \mathrm{GH} \\
\text { Integrated power } 1350 \mathrm{MH}-\mathrm{s}\end{array}$ \\
\hline $\begin{array}{l}\text { OMEG/ } / \text { W } \\
\text { (NeN Mexico) }\end{array}$ & 8 & 5 & $\times 10^{13} \mathrm{thrm}$ & 5.1 dla $\times 61$ & 1.2 & MTR-type core \\
\hline $\begin{array}{l}\text { MITR } \\
\text { (Massachusetts) }\end{array}$ & 4.9 & $\stackrel{3}{1}$ & $\begin{array}{l}\times 1013 \text { thrm } \\
\times 10^{14} \text { fast }\end{array}$ & $\begin{array}{l}4.5 \text { dia } \times 61(?) \\
2.9 \text { dia } \times 61(2) \\
6.9 \times 5.1 \times 61\end{array}$ & $\begin{array}{l}0.9 \\
0.3 \\
2.1\end{array}$ & Vertical thimbles \\
\hline $\begin{array}{l}\text { BSR. } \\
\text { (Tenresse) }\end{array}$ & 2 & 5.5 & $\times 10^{12} \mathrm{thrm}$ & $7.6 \times 7.6 \times 61$ & 3.5 & Also cryogenic facility \\
\hline $\begin{array}{l}\text { HFIR } \\
\text { (Tennesse) }\end{array}$ & 100 & $\begin{array}{r}1.3 \\
9 \\
2 \\
1.5\end{array}$ & $\begin{array}{l}\times 1015 \text { fast } \\
\times 1014 \text { thrm } \\
\times 1014 \text { thrm } \\
\times 10^{14} \text { thrm }\end{array}$ & $\begin{array}{l}13 \text { dia } \times 51^{*} \\
1.3 \text { dia } \times 51 \text { (8) } \\
3.8 \text { dia } x 51 \text { (i) } \\
7 \text { dia } \times 51 \text { (2) }\end{array}$ & $\begin{array}{l}6.8 \\
0.1 \\
0.6 \\
2.0\end{array}$ & $\begin{array}{l}\text { * Maximum dianeter of flux } \\
\text { trap }\end{array}$ \\
\hline $\begin{array}{l}\text { ORR } \\
\text { (Tennesse) }\end{array}$ & 30 & $\begin{array}{r}4.5 \\
4\end{array}$ & $\begin{array}{l}\times 10^{14} \text { fast } \\
\times 10^{13} \text { fast }\end{array}$ & $\begin{array}{l}7.859 \times 38.4 \\
71 \times 76 \times 63\end{array}$ & $\begin{array}{r}2.3 \\
339.9\end{array}$ & $\begin{array}{l}\text { Any core position } \\
\text { Poolside irradiation }\end{array}$ \\
\hline $\begin{array}{l}\text { MURZ } \\
\text { (Missouri) }\end{array}$ & 10 & $\begin{array}{l}4.6 \\
3.5\end{array}$ & $\begin{array}{l}\times 10^{14} \text { thrm } \\
\times 10^{13} \text { fast }\end{array}$ & 3.8 dia $\times 75(3)$ & 0.9 & Flux trap positions \\
\hline
\end{tabular}


TABLE 5. (continued)

\begin{tabular}{|c|c|c|c|c|c|}
\hline Reactor & $\begin{array}{l}\text { Power } \\
(M W)^{d}\end{array}$ & $\begin{array}{c}\text { Exjeriment } \\
\text { Neutron } \mathrm{F}_{\mathrm{L}} \mathrm{F}^{\mathrm{a}} \\
\left(\mathrm{n} / \mathrm{cm}^{2} / \mathrm{s}\right) \\
\end{array}$ & $\begin{array}{c}\text { Experiment Si=e } \\
(\mathrm{cm})^{\mathrm{a}}\end{array}$ & $\begin{array}{c}\begin{array}{c}\text { Test position } \\
\text { Experiagent volume } \\
\text { ( })\end{array} \\
\end{array}$ & Notes \\
\hline $\begin{array}{l}\text { FFTF } \\
\text { (Washington) }\end{array}$ & .400 & $4.6 \times 10^{15}$ fast & $\begin{aligned} 7 \text { dia } \times 91(2) \\
11 \text { dia } \times 91(3)\end{aligned}$ & $\begin{array}{l}3.5 \\
8.6\end{array}$ & $\begin{array}{l}\text { Closed loops } \\
\text { open loops; in-core dianeter } \\
\text { Any fuel or reflector possition }\end{array}$ \\
\hline $\begin{array}{l}\text { GETR } \\
\text { (California) }\end{array}$ & 50 & $\begin{array}{l}3.3 \times 10^{14} \text { thrm } \\
2.8 \times 10^{14} \text { thrm } \\
2.7 \times 10^{14} \text { thrm }\end{array}$ & $\begin{array}{l}7.4 \text { dia } \times 91(1)^{*} \\
7.4 \text { dia } \times 91(2)^{*} \\
3.8 \text { dia } \times 91(E)\end{array}$ & $\begin{array}{l}3.9 \\
3.9 \\
1.0\end{array}$ & $\begin{array}{l}\text { In standby condition } \\
* \text { Thru-loop capability }\end{array}$ \\
\hline \multirow[t]{3}{*}{$\begin{array}{l}\text { BR2 } \\
\text { (Belgium) }\end{array}$} & 50 & $\begin{array}{r}6 \times 1014 \text { thrm } \\
2.4 \times 10^{15} \mathrm{fast}\end{array}$ & 20.3 dia $\times 91$ & 29.5 & Center hole \\
\hline & & $\begin{array}{l}2.8 \times 10^{14} \text { thrm } \\
9.4 \times 10^{14} \text { fast }\end{array}$ & $20.3 \mathrm{dta} \times 91(t)$ & 29.5 & Thru holes \\
\hline & & $\begin{array}{l}2.8 \times 10^{14} \text { thrn } \\
9.4 \times 10^{14} \text { fast }\end{array}$ & 5 día $\times 91(10)$ & 1.8 & $\begin{array}{l}\text { Several other Irregular positions } \\
\text { Fluxes given are naximum values }\end{array}$ \\
\hline $\begin{array}{l}\text { DR-3 } \\
\text { (Denmark) }\end{array}$ & 10 & $1 \times 10^{14}$ thrn & $17.8 \mathrm{dia} \times 61$ & 15.2 & \\
\hline \multirow[t]{2}{*}{$\begin{array}{l}\text { HFR } \\
\text { (Nether lands) }\end{array}$} & 20 & $\begin{array}{l}2 \times 10^{14} \mathrm{thrm} \\
5 \times 10^{14} \mathrm{fast}\end{array}$ & 14.5 dia $\times 60^{\circ}$ & 9.9 & Thru hole \\
\hline & & $\begin{array}{r}1.5 \times 10^{14} \text { thrm } \\
4 \times 10^{14} \text { fast }\end{array}$ & $6 \mathrm{dia} \times 60$ & 1.7 & In-core U-tube \\
\hline SAFARI-1 & 20 & $\begin{array}{l}4 \times 10^{14} \max \\
\text { thrm }\end{array}$ & $15 \times 15 \times 61$ & 13.7 & Thru-10op capability \\
\hline
\end{tabular}

a. The sources of this informetion were the Research, Training, T⿰氵st, anc Production Reactor Directory (ANS, 1979) and the Directory of Nuc liear Reactors, Vols. I-4 (AIEA, $\bar{A}$, 959 ). 
An additional consideration for fusion testing in a fission reactor is the neutron energy spectrum. As an example, figure 6 shows the calculated fus ion neutron spectrum for the ORNL/Westinghouse blanket concept at the first wall. Also plotted is the expected spectrum for the same module in the ETR core, assuming that there is a surface heating layer of hel ium-3. Except for the lack of $14 \mathrm{MeV}$ neutrons and a larger component of thermal neutrons, the spectra are quite similar, and should induce similar materials damage.

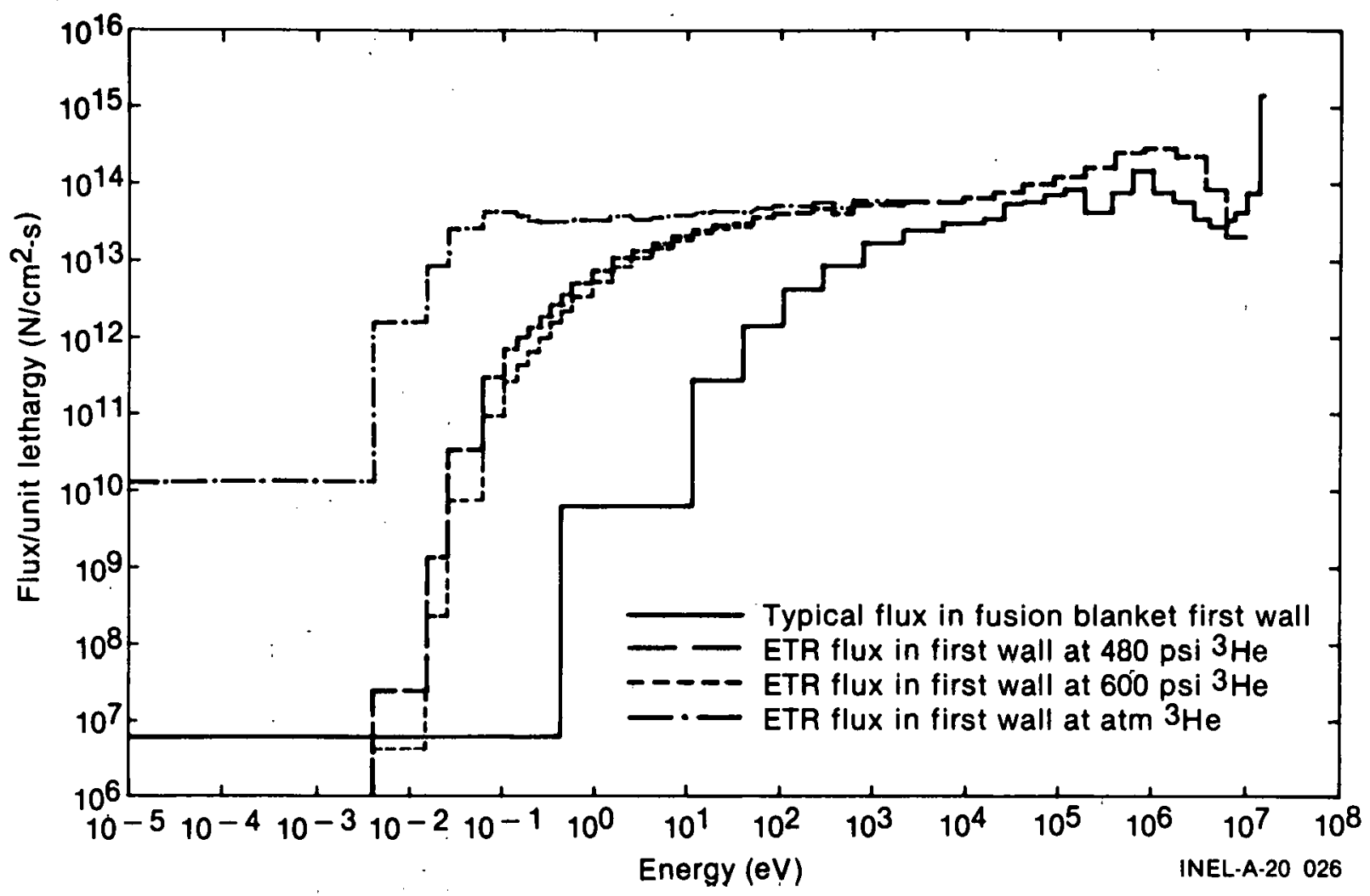

Figure 6. Comparison of anticipated neutron flux spectra for ORNL/ Westinghouse TNS module in a fiss ion reactor.

Several factors influence reactor availability. Among these are the degree of dedication to $B / S$ research, flexibility of operating schedule for concurrent experiments, and operating costs.' Modifications required to accommodate fusion testing will also influence the availability of a reactor. 
Most of the test reactors 1 isted in Tables 4 and 5 have tubes with square or circular cross-sections which penetrate the core in the axial direction. These facilities are suitable for capsule-type tests up to several on in diameter.

The reactors listed are suitable for testing without any modifications to the core. Other reactors, not listed, may also be suitable with some degree of modification to their cores and/or structures.

Costs for irradiation tests of this sort are based on irradiation units (IUs). Although several definitions are in use, the most commonly used IU is $10^{20}$ nvt in one cubic inch. Representative costs for this un it for several candidate reactors are shown in Table 6.

TABLE 6. IRRADIATION COSTS AT SEVERAL REACTORS

\begin{tabular}{lr} 
Reactor & $\begin{array}{r}\text { FY-1981 } \\
\text { IU Costs }\end{array}$ \\
\hline ATR & $\$ 91.59$ \\
ETR & $20.00^{\mathrm{a}}$ \\
MURR & $87.64^{\mathrm{b}}$ \\
MITR & $373.75^{\mathrm{c}}$ \\
HFBR & $264.15^{\mathrm{d}}$
\end{tabular}
a. In parallel with other experiments.
b. In the flux trap.
c. In high flux vertical thimble.
d. In a high fiux capsule position. 


\subsection{Strategy for Use of Supporting Nonnuclear Facilities}

As with Phase-I tests, the principle function of supporting nonnuclear testing in the post-Phase-I nuclear strategy will be to produce qualified experiments 'for testing in a nuclear reactor. This function has two aspects.

The first of these is that any individual test piece which will undergo nuclear testing must be thoroughly pretested and verified, in order to assure that it cannot jeopardize the reactor under any forseeable conditions. The testing required for this assurance is usually proof testing of an individual test piece.

In contrast, the second functional aspect of supporting nonnuclear testing is in developing information for use in the design of the nuclear test piece. Typically, nonnuclear testing may be used to make a preliminary selection of several general test-piece concepts to pursue. In addition, nonnuclear testing could be used to establish some of the bas ic information required for the design of more complex test pieces, and so on. In performing this type of testing, it is likely that most of the necessary test-piece verification would be performed; thus, little extra proof testing should be required.

This second functional aspect is very similar to that of nonnuclear testing in a nonnuclear strategy. Therefore, the nonnuclear testing for either the nuclear or nonnuclear strategy will be quite similar. The principal difference $w i l l$ be that at some point in the program, the strategies will diverge. This point will be that beyond which the desired information can be obtained more effectively with one or more nuclear tests.

Because the actual experiment us ing nuclear facilities in post-Phase-I testing cannot now be specified with certainty, the supporting nonnuclear tests must also wait for their definitions until the $B / S$ designs are sufficiently mature to warrant designing tests of these $k$ inds. As was stated, the basic approach is to use nonnuclear facilities in their conventional, supporting role on an as-required $b$ as is. 


\section{RECOMMENDAT IONS}

On the bas is of this study, and on the accompanying study of the development of a strictly nonnuclear test strategy. 6 , it is recommended that the solid breeder concept investigation be adopted as the initial experimental effort during Phase I of TPE II. The primary motivation beh ind this recommendation is that the sol id breeder concept has been identified as one which could be addressed most productively in the immediate future. A secondary, but important, reason is that for th is investigation, the proposed nuclear and nonnuclear strategies involve identical testing during the Phase-I time period. Thus, it is not necessary to commit to either approach in order to begin testing.

It is further recommended that the nuclear test strategy be aggressively pursued. This would require not only undertaking the outlined, nonnuclear, Phase-I testing program, but also continuing of detailed planning efforts, leading toward a nuclear test early in the post-Phasc. I time frame. 


\section{REFERENCES}

1. V. A. Maroni, "Statement of Work for Planning, Research, and Development Relevant to TPE II of the Office of Fusion Energy First Wall/ Blanket/Sh ield Engineering Test Program, "Revis ion 2, Argonne National Laboratory, July $1,1981$.

2. A. R. Veca, et al., Test Program Element II Blanket and Sh ield ThermalHydraul ic and Thermomechanical Testing of the First WaT/7BTanket/ShieTd Engineer ing Test Program--Data Needs Assessment Report, GA-C16571,. october 1981.

3. G. A. Deis, et al., Evaluation of Alternative Methods of Simulating As ymmetr ic Bulk Heating in Fus ion Reactor Blanket/Sh ield Components, EGG-FT-5603, October 1981.

4. A. G. Ware and G. R. Longhurst, Test Program Element II Blanket and Shield Thermal-Hydraulic and Thermomechanical Testing, Exper imental Facility Survey, EGG-FT-5626, November. T98T. .

5. P.Y.S. Hsu, et al., Fus ion Technology Development--First Wall/Blanket Sys tem and Component Testing in Existing FacilftTes, EGG-FT-5281, December 1980 .

6. A. R. Veca, et al., Development of a Nonnuclear Test Strategy for Test Progr am Element II, GA-C16589, November 1981. 